\author{
J.A.Renshaw \\ Leeds Metropolitan University \\ Usability North \\ Caedmon Hall, Beckett Park \\ $+44(0) 1138128608$ \\ t.renshaw@leedsmet.ac.uk
}

\title{
Eye Tracking in Practice
}

\author{
N.Webb \\ Amberlight Partners Ltd \\ 58 Bloomsbury St., \\ London WC 1B 3QT, UK \\ $+44(0) 2027307779$ \\ Natalie@amber-light.co.uk
}

\begin{abstract}
This paper describes the practical side of eye tracker use in the field of human computer interaction. The paper relates to usability evaluations in practice covering those topics of primary importance to practitioners including the business case for eye tracking and the technique's benefits and limitations. The authors describe techniques, based on practical experience, to be deployed to ensure success with eye tracking and provide some useful links and references for those contemplating adoption of the technique. Ideas on future practical areas of deployment are discuss.
\end{abstract}

\section{Categories and Subject Descriptors}

\section{General Terms}

\section{Keywords}

Eye tracking, application, evaluation.

\section{INTRODUCTION}

The purpose of this paper is to describe proposals for a presentation to be given by the authors, as part of the HCI Practice track, on the more practical side of the use of eye trackers in the field of human computer interaction. This will primarily cover usability but there will be references to other areas which are of topical interest. The presentation will not cover the psychological or physiological theoretical concepts behind eye tracking unless these issues are raised by questions from the audience.

\section{PRESENTATION OUTLINE}

- Background

- What it is the audience is going to get out of this presentation
- The financial case for eye tracking
- Some FAQs about Eye Tracking
$\circ \quad$ Wider benefits of eye tracking
- What makes a successful eye tracking based evaluation
- Areas of Application

- Useful books and links

- Summary

\section{BACKGROUND}

The problem with eye tracking is that when something is detected in a study the recipient of the information invariably says "I knew that already" or "a questionnaire would have picked that up!"

However, in reality it is doubtful that observers would be able to describe where players look whilst playing first shooter/racing car games and how their fixations are distributed over the screen, or what influence a film directors use of frames, camera angle or depth of focus has over eye movements, or where most of the audience look frame by frame when viewing a film. Everyone knows that an expert will faithfully recall the secret short cuts/areas of interest he/she uses when working with an application, or where a child's eyes are looking as you re-read a sentence of a story to them. Or do they? The determination of these things is possible with eye tracking but difficult with the more conventional evaluation tools.

The point being made is that the trick of getting eyetracking the recognition it deserves is to get the eye tracker to provide answers to questions that interviews and questionnaires have not a hope of answering economically if at all. Hopefully by the end of the current presentation the audience will have ideas about what those questions could be.

\subsection{The Financial Case for Eyetracking}

A state of the art eye tracker costs less than $£ 20000$ in a readyto-use state. The equipment is very easy to use, robust and versatile for, in addition to eye movements, it records and time stamps mouse clicks, key depressions, web pages visited and can be also used as a normal computer terminal. Used in combination with a webcam it is a real productivity aid saving both analysts' time and adding to a study's accuracy. Participant processing rates can exceed 2 per hour for a moderately complex study.

Of course expense is a relative thing, some might prefer to replace the accountant's company car, some may not mind loosing a couple of contracts a year because their business could not offer the services a client wanted, some may not really appreciate the time spent at the coalface taking notes and/or wracking the analyst's memory for the context a particular note taken during an interview.

It is possible that an investment of this nature could be recouped within 18 months or less. 


\subsection{Table 1.Some FAQs about Eye Tracking}

\begin{tabular}{|c|c|c|c|c|}
\hline Question & & Response 1 & & Response 2 \\
\hline $\begin{array}{l}\text { What does eye } \\
\text { tracking tell me } \\
\text { that other } \\
\text { techniques don't? }\end{array}$ & & $\begin{array}{l}\text { Quickly, easily and reasonably reliably where } \\
\text { people look in real time and where they don't. } \\
\text { For how long/fleetingly they look at specific } \\
\text { areas or where they don't. The sequences of } \\
\text { their gazes }\end{array}$ & & \\
\hline $\begin{array}{l}\text { Well if they are } \\
\text { so marvellous } \\
\text { why haven't they } \\
\text { caught on more? }\end{array}$ & & $\begin{array}{l}\text { More than what? Are you sure you know for } \\
\text { certain how many leading edge usability } \\
\text { consultancies } \underline{\text { don't }} \text { have one? }\end{array}$ & $\begin{array}{l}\text { But also } \\
\text { because }\end{array}$ & $\begin{array}{l}\text { The concept was new. Before } \\
\text { technological improvements } \\
\text { were made the techniques was } \\
\text { perceived as invasive (one had } \\
\text { to be in a lab and wear } \\
\text { helmets), unreliable and } \\
\text { temperamental and ROI } \\
\text { uncertain. }\end{array}$ \\
\hline $\begin{array}{l}\text { Do you need } \\
\text { much training to } \\
\text { run an eye } \\
\text { tracking session? }\end{array}$ & No & $\begin{array}{l}\text { Operating the equipment and conducting the all } \\
\text { important calibration process has been made } \\
\text { very easy by the manufacturers }\end{array}$ & and yes & $\begin{array}{l}\text { As with any evaluation using } \\
\text { human beings it is important to } \\
\text { plan ahead. The design of the } \\
\text { study needs to be thought } \\
\text { through if meaning full results } \\
\text { are to be obtained. }\end{array}$ \\
\hline $\begin{array}{l}\text { Do evaluations } \\
\text { take long to do? }\end{array}$ & No & $\begin{array}{l}\text { It's a bit like "how long is a piece of string". } \\
\text { But eye tracking yields a lot of data very } \\
\text { quickly. Sensible results can be derived in as } \\
\text { little as } 15 \text { minutes per participant. } \\
\text { Visual renditions of the data are almost } \\
\text { instantaneously available. } \\
\text { Data is easily exported to spreadsheet } \\
\text { applications }\end{array}$ & and yes & $\begin{array}{l}\text { Large volumes of data can be } \\
\text { generated. Interpretation of the } \\
\text { data requires some knowledge } \\
\text { of the theory behind visual } \\
\text { perception, attention and } \\
\text { statistics. For qualitative } \\
\text { studies it takes time to match } \\
\text { visual patterns to user } \\
\text { behaviour. }\end{array}$ \\
\hline $\begin{array}{l}\text { Can eye tracking } \\
\text { be incorporated } \\
\text { into normal } \\
\text { evaluation } \\
\text { processes? }\end{array}$ & Yes & $\begin{array}{l}\text { A modern state of the art eye tracking can be } \\
\text { integrated into a website evaluation at any stage } \\
\text { in the process and given that the eye tracker can } \\
\text { record urls visited, mouse clicks and keyboard } \\
\text { depressions it can be seen as a great } \\
\text { productivity aid. }\end{array}$ & and no & $\begin{array}{l}\text { Long eye tracking sessions } \\
\text { may generate large data files } \\
\text { which can be difficult to } \\
\text { manage and may lead to } \\
\text { system crashes. Java elements } \\
\text { will not be shown in some } \\
\text { renditions of the gaze data }\end{array}$ \\
\hline $\begin{array}{l}\text { Do clients like the } \\
\text { outcomes? }\end{array}$ & Yes & $\begin{array}{l}\text { An eye tracker quickly generates authoritative } \\
\text { visually appealing outputs }\end{array}$ & and no & $\begin{array}{l}\text { Clients want concise clear } \\
\text { answers, they give the } \\
\text { impression of not wanting to } \\
\text { hear about complexity, } \\
\text { probability and statistical } \\
\text { significance. }\end{array}$ \\
\hline $\begin{array}{l}\text { Can clients view } \\
\text { eye movements } \\
\text { live? }\end{array}$ & Yes & $\begin{array}{l}\text { Clients can view eye movements live on a } \\
\text { separate screen }\end{array}$ & But & $\begin{array}{l}\text { There are some technical } \\
\text { restrictions. }\end{array}$ \\
\hline $\begin{array}{l}\text { Can eyetracking } \\
\text { do everything } \\
\text { including making } \\
\text { the tea? }\end{array}$ & & $\begin{array}{l}\text { Eye tracking is not a silver bullet. It augments } \\
\text { other techniques rather than being a panacea for } \\
\text { all ills. There are still a few technical } \\
\text { limitations e.g. showing fixations and scan } \\
\text { paths over the Flash element of a website is, at } \\
\text { the time of writing, not possible. }\end{array}$ & No & They don't make the tea! \\
\hline
\end{tabular}




\subsection{The Wider Benefits of Eye Tracking}

- Users' attention/inattention to specific areas can be demonstrated

- Some indication of strategies in problem solving can be elicited

- Permits exploration of problems with menus, navigation link issues and/or status indicator salience

- The data collected is not dependant on a participant's memory

- A large volume of objective quantifiable data can be collected

- $\quad$ Some eye movement patterns are involuntary being natural reactions to the visual scene and consequently less prone to participant bias

- Visual summaries of participant behaviour are quickly and easily rendered and data exported to databases or spreadsheets within a few key strokes

- The equipment used can be unobtrusive

- Complements other evaluation techniques and can be used to triangulate findings

\subsection{What Makes for a Successful Eye Tracking Evaluation?}

The following suggestions are made with the intention of ensuring success in conducting an eye tracking based evaluation. They have been gleaned by the authors from several years of practical experience

- Careful selection of the problem to be resolved in terms of playing to the strengths of the eye tracking technique and the economics of getting to an answer through other methodologies.

- $\quad$ Thinking through the possible outcomes and expected results.

- Careful planning, selection and rehearsal of the tasks to minimise the occurrence of an unexpected event and to make sure that the tasks are sufficiently demanding and relevant to avoid breeches of eye tracking theory.

- Careful and accurate calibration of the equipment to each participant. Many participants change their seating position after calibration it is important that this potential risk is avoided by getting them comfortable and in their normal posture before calibration starts.

- Allow time for analysis

- Use the recording of the eye movements as a prompt to memory during subsequent post evaluation interviews

- Use a microphone to record user reaction during and after the eye tracking evaluation and to inform post evaluation analysis of same.

- Make sure the evaluation is conducted within the relevant environmental ambiance.

\subsection{Areas of Application for the Technique}

- Evaluations of websites and productivity applications: the assessment of placement, salience and organisation of menus, advertisements, help buttons, system status advice

- Efficacy of search engine results displays

- User reaction to variations in advertising location and format

- Behaviour differences between experts and novices in (for example) reading, mammogram examination and location of metal fatigue in aircraft airframes

- Analysis of game playing and film viewing behaviours.

\section{USEFUL ARTICLES and LINKS}

Eye tracker manufacturers' websites: ASL, SMI and Tobii

Usability Practitioners: Amberlight; Bunnyfoot, Usability North to name but a few.

http://www.poynterextra.org/eyetrack2004/main.htm

http://www.cs.tufts.edu/ jacob/papers/ecem.pdf

\section{SUMMARY}

In this paper supporting the presentation the authors have delivered details about eye tracking as an evaluation tool albeit only in outline. Interest in this topic is growing. Both the advantages and limitations of this technique have been presented no punches have been pulled. Overall the technique is a cost effective, technologically advanced, accurate, robust, mobile, versatile evaluation tool; a more than useful addition to a practitioner's usability repertoire. The technique demands forward planning, vigilance against confounding effects, staff training in its use and data analysis skills. So what's new? All the techniques used in a practitioner's business make similar demands... don't they?

\section{REFERENCES}

[1] Goldberg, J.H. and Wichansky, A.M. (2003) In The Mind's Eye: Cognitive and applied aspects of Eye Movement Research (Eds. J.Hyona, R. Radach and H.Deubel. Oxford, Elsevier Science)

[2] Renshaw, J.A. and Webb, N. (2006). Getting a measure of satisfaction from eye tracking in Practice. CHI 2006 Workshop, Montreal, Canada.

[3] Webb,N. and Renshaw,J.A. (2006). Adding Value with Eye tracking. UPA 2006 Workshop, Omni Interlocken Broomfield, Colorado, USA.

[4] Renshaw,J.A. and Webb,N., (2005) Commercial Uses of Eye Tracking. HCI 2005 Workshop, Edinburgh, Scotland.

[5] Duchowski, A.T. (2003). Eye Tracking Methodology: Theory and Practice, Springer. 